\title{
Comparative analysis of two immunohistochemical methods for antigen retrieval in the optical lobe of the honeybee Apis mellifera: Myosin-v assay
}

\author{
LUCIANA KAREN CALÁBRIA ${ }^{1}$, RENATA ROLAND TEIXEIRA ${ }^{1}$, \\ SYBELLI MAGDA COELHO GONÇALVES ${ }^{1}$, ANDREIA BARCELOS PASSOS LIMA ${ }^{1}$, \\ ANA ALICE DINIZ DOS SANTOS ${ }^{2}$, ANTÔNIO ROBERTO MARTINS ${ }^{3}$ \\ and FOUED SALMEN ESPINDOLA ${ }^{1 *}$
}

\begin{abstract}
${ }^{1}$ Instituto de Genética e Bioquímica, Universidade Federal de Uberlândia, Av. Pará, 1720, Bloco 2E, sala 39A, CEP 38400-902, Uberlândia-MG, Brazil.

${ }^{2}$ Instituto de Ciências Biomédicas, Histologia e Embriologia, Universidade Federal de Uberlândia, Av. Pará, 1720, Bloco 2B, CEP 38400-902, Uberlândia-MG, Brazil.

${ }^{3}$ Departamento de Farmacologia, Faculdade de Medicina de Ribeirão Preto Universidade de São Paulo, Av. Bandeirantes, 3900, Prédio Central, CEP 14049-900, Ribeirão Preto-SP, Brazil.
\end{abstract}

\begin{abstract}
The present study compared two heating methods currently used for antigen retrieval (AR) immunostaining: the microwave oven and the steam cooker. Myosin-V, a molecular motor involved in vesicle transport, was used as a neuronal marker in honeybee Apis mellifera brains fixed in formalin. Overall, the steam cooker showed the most satisfactory AR results. At $100{ }^{\circ} \mathrm{C}$, tissue morphology was maintained and revealed epitope recovery, while evaporation of the AR solution was markedly reduced; this is important for stabilizing the sodium citrate molarity of the AR buffer and reducing background effects. Standardization of heat-mediated AR of formalin-fixed and paraffin-embedded tissue sections results in more reliable immunostaining of the honeybee brain.
\end{abstract}

Key terms: antigen retrieval, microwave oven, steam cooker.

\section{INTRODUCTION}

Immunohistochemistry (IHC) is an important technique for pathology diagnostics and investigative studies ${ }^{1}$. In the first step of IHC, tissue is fixed in a solution that usually contains formalin; however the use of this component is extensively discussed because many antigens interact with the chemical ${ }^{1-4}$.

Antigen retrieval (AR) is a routine immunohistochemical procedure that exposes antigenic epitopes in order to enhance immunostaining. During the AR step, the tissues are subjected to high temperatures in a solution containing metallic salts (sulfate zinc, zinc chloride and aluminum chloride) dissolved in a sodium citrate buffer at $\mathrm{pH}$ 6.0-9.0 or distilled water ${ }^{5}$. Although this procedure is very simple, it contains factors that can affect immunostaining, such as heating conditions and the $\mathrm{pH}$ of the solutions ${ }^{6}$. Since the AR technique was developed ${ }^{4,7}$, publications have confirmed its efficiency through immunohistochemical results, and the literature can be divided into periods before and after $\mathrm{AR}^{8,9}$.

The growing use of AR-IHC has prompted several modifications to the method, in particular modifications related to the solutions and heating methods

\footnotetext{
*Correspondent author: Foued Salmen Espindola, Universidade Federal de Uberlândia - Instituto de Genética e Bioquímica, Laboratório de Bioquímica e Biologia Molecular, Campus Umuarama Bloco 2E sala 39A, CEP: 38400-902 Telefone: 55 (34) 3218-2477 and Fax: 55 (34)3218-2203, E-mail: fsespindola@ gmail.com
} 
used $^{2,10-13}$. The first report ${ }^{2}$ of heating for AR-IHC utilized a microwave oven and a conventional heating element (hot plate), and it was demonstrated that the microwave oven produced better results. Then, other methods utilizing the autoclave $2,12,14-16$, pressure cooker ${ }^{17,18}$, water bath ${ }^{19}$ and steam heating were developed ${ }^{20}$. However, studies comparing heating methods have resulted in conflicting conclusions regarding which is the most effective.

Martins et $a l .{ }^{21}$ used anti-myosin- $\mathrm{V}$ as a neuronal marker for the human central nervous system in an experiment testing AR with a microwave oven, and the immunostaining produced satisfactory results. Myosin-V is a molecular motor highly expressed in the brain ${ }^{22}$ and is conserved in a variety of species ${ }^{23}$, and broadly distributed regionally ${ }^{24-26}$. This protein participates in many different functions, including vesicle trafficking, structural support, and mRNA trafficking 22,27-30.

Biochemical data obtained using vertebrate anti-myosin-V revealed its presence in the honeybee Apis mellifera brain, making it an efficient neuronal marker for this invertebrate nervous system. We thus evaluated two heating methods for AR-IHC, the microwave oven and the steam cooker, in order to discover which method of immunostaining was more efficient, and to standardize this methodology for the invertebrate nervous system.

\section{MATERIAL AND METHODS}

\section{Biological material}

Honeybees Apis mellifera were captured in the Jardim Experimental, Instituto de Biologia, Universidade Federal de Uberlândia, in Uberlândia-MG. The honeybees were anesthetized on ice, and then fixed on plates with paraffin and entomological pushpins. The brains were dissected and fixed in $4 \%$ paraformaldehyde ( $\mathrm{pH} 7.4$ ) according to McLean \& Nakane ${ }^{31}$ for two hours at $25^{\circ} \mathrm{C}$, dehydrated in ethylic alcohol, embedded in paraffin, and mounted as $5 \mu \mathrm{m}$ sliced sections with $0.2 \%$ gelatin-chromo.

\section{Hematoxylin-eosin}

The sections were washed with distilled water for 10 minutes, stained with hematoxylin for 12 minutes, washed in water for 15 minutes, stained with eosin for 1 minute and then mounted with Permount.

\section{Immunohistochemistry}

The sections were blocked with $4.5 \%$ hydrogen peroxide in phosphate-saline buffer for 15 minutes. Then, the sections were incubated with $0.1 \mathrm{M}$ Tris-glycine buffer, $\mathrm{pH} 7.4$, for 30 minutes and buffer B $(20 \mathrm{mM}$ sodium phosphate, $\mathrm{pH} 7.4 ; 0.4 \mathrm{M}$ $\mathrm{NaCl} ; 0.3 \%$ Triton $\mathrm{X}-100)$ supplemented with $5 \%$ dried milk and goat inactive serum 1: $6(\mathrm{v} / \mathrm{v})$ for 4 hours. The primary antibody (anti-myosin-V heavy chain, affinity-purified, polyclonal generated in rabbits inoculated with bacterially expressed head domain of myosin-Va, initially characterized by Espreafico et al. ${ }^{25}, 750 \mu \mathrm{g} / \mathrm{mL}$ ), diluted 1: 200, was incubated with the samples for 10 hours at $4{ }^{\circ} \mathrm{C}$, and the secondary antibody (antirabbit $\mathrm{IgG}$ ) conjugated with peroxidase (Amersham Bioscience, UK) diluted 1: 200 was incubated with the samples for 1 hour at $25^{\circ} \mathrm{C}$. For the final step, $10 \mathrm{mg} / \mathrm{mL}$ DAB (3, 3'- diaminobenzidine) was used, and the reaction was quenched with water. After that, the sections were dehydrated and the slides were mounted with Permount.

\section{Antigen retrieval}

The control sections did not undergo the AR method and were processed in the same manner as the other test sections. We tested two methods for antigen retrieval to expose myosin- $\mathrm{V}$ to its antibody in the formalin fixed honeybee brain and evaluated temperature and $\mathrm{pH}$ before and after $\mathrm{AR}$ methods. Besides, negative control consisted of the omission of the primary antibody in the reaction and AR with steam cooker. 
Microwave oven (Sharp Carousel II, mod. RB-4A33, power 100\%): the slides were incubated in $10 \mathrm{mM}$ sodium citrate buffer, $\mathrm{pH} 6.0$ for 10 minutes, with an interval of 1 minute and another heating step of 5 minutes.

Steam cooker (Tefal Steam Cuisine, mod. 364688, power 100\%): the slides were incubated in $10 \mathrm{mM}$ sodium citrate buffer, $\mathrm{pH} 6.0$ for 30 minutes at $100{ }^{\circ} \mathrm{C}$, heated in advance.

Temperatures and $\mathrm{pH}$ initials were $25^{\circ} \mathrm{C}$ and 6.0, and thereupon AR were $93{ }^{\circ} \mathrm{C}$ and 5.93 for microwave oven and $85{ }^{\circ} \mathrm{C}$ and 5.94 for steam cooker.

\section{RESULTS}

\section{Brain histology}

Staining with hematoxylin-eosin in the worker honeybee Apis mellifera brain revealed the structure of the ocelli, mushroom bodies, alpha lobe, beta lobe, antennal lobe and subregions of the optical lobe: the medulla, external chiasm, lamina, fenestrated layer and retina, with its pigments, as shown in figure 1 .

\section{IHC without AR}

The brain sections that underwent immunohistochemistry without antigen retrieval showed nonexistent immunostaining in the optical lobe (Figure 2 , no antigen retrieval). In the slices stained with hematoxilin-eosin it was possible to clearly visualize retinal pigmentation in the optical lobe that was not present when immunostaining with anti-myosin- $\mathrm{V}$.

\section{AR-IHC with the microwave oven}

The intensity of immunostaining when using a microwave oven for AR heating was moderate (orange staining) in the retina and fenestrated layer, as compared to the other methods of AR heating; this is shown in figure 2 , microwave oven.

\section{AR-IHC with the steam cooker}

AR done in the steam cooker showed the best results when compared with $\mathrm{AR}$ done in the microwave oven or immunohistochemistry without AR. The intensity of immunostaining was strong (dark brown) in the entire optic
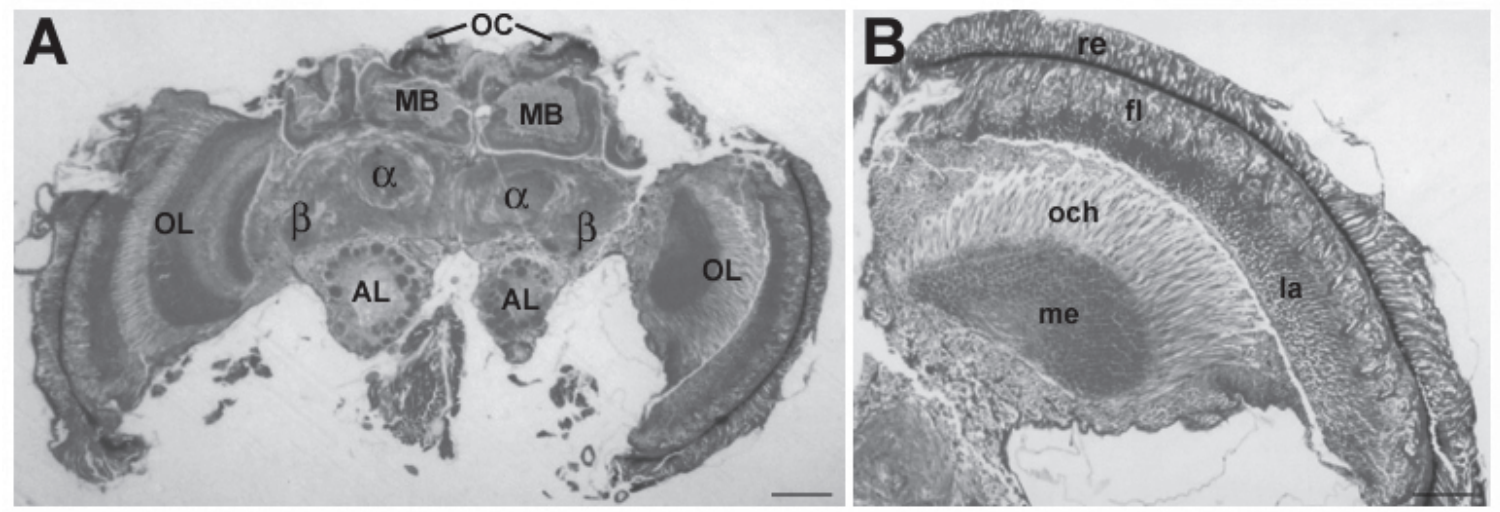

Figure 1: Panoramic view of the honeybee Apis mellifera brain stained with hematoxylineosin.

Horizontal section of the honeybee brain shows the regions: ocelli (OC), mushroom bodies (MB), antennal lobe (AL), alpha lobe (a), beta lobe (b) and optical lobe (OL); Scale bar $=200 \mathrm{~mm}$. (B) Detail of the optical lobe with its subregions: retina (re), fenestrated layer (fl), lamina (la), outer chiasm (och) and medula (me); Scale bar $=80 \mathrm{~mm}$. 
lobe, including retina, fenestrated layer, lamina and outer chiasm (Figure 2, steam cooker).

\section{DISCUSSION}

Fixation in formalin promotes multiple bonds between amino groups, as well as the formation of methylene bridges between the amino acids present in other proteins in the tissue. These multiple bonds block the antigen epitopes, and the antibody cannot recognize the specific antigen. The forces and bonds that participate in immune reactions are electrostatic charges, van der Waals forces, hydrogen bonds and hydrophobic interactions ${ }^{32}$. Therefore, the AR procedure, by using enzymatic methods or heating $33-315$, can expose antigenic epitopes in order to enhance immunostaining in the tissue ${ }^{1}$, stabilizing the electrostatic forces that are necessary to bind the antigen and antibody ${ }^{32}$.

Shi et al. ${ }^{2}$ compared microwave oven and protease digestion, a enzymatic method, and the first was clearly superior, particularly with antigens, such as vimentin in human tonsil. For some antigens, the enzymatic method is preferable to heat mediated antigen retrieval, and vice versa with others. The enzymatic method tends to be a much gentler process than the heat mediated method, so it is best suited to more sensitive tissues. However, the enzymatic method tends to take much longer and is more technically demanding. In the optical lobe of the honeybee Apis mellifera, heat methods were efficient and the microwave oven further moderated
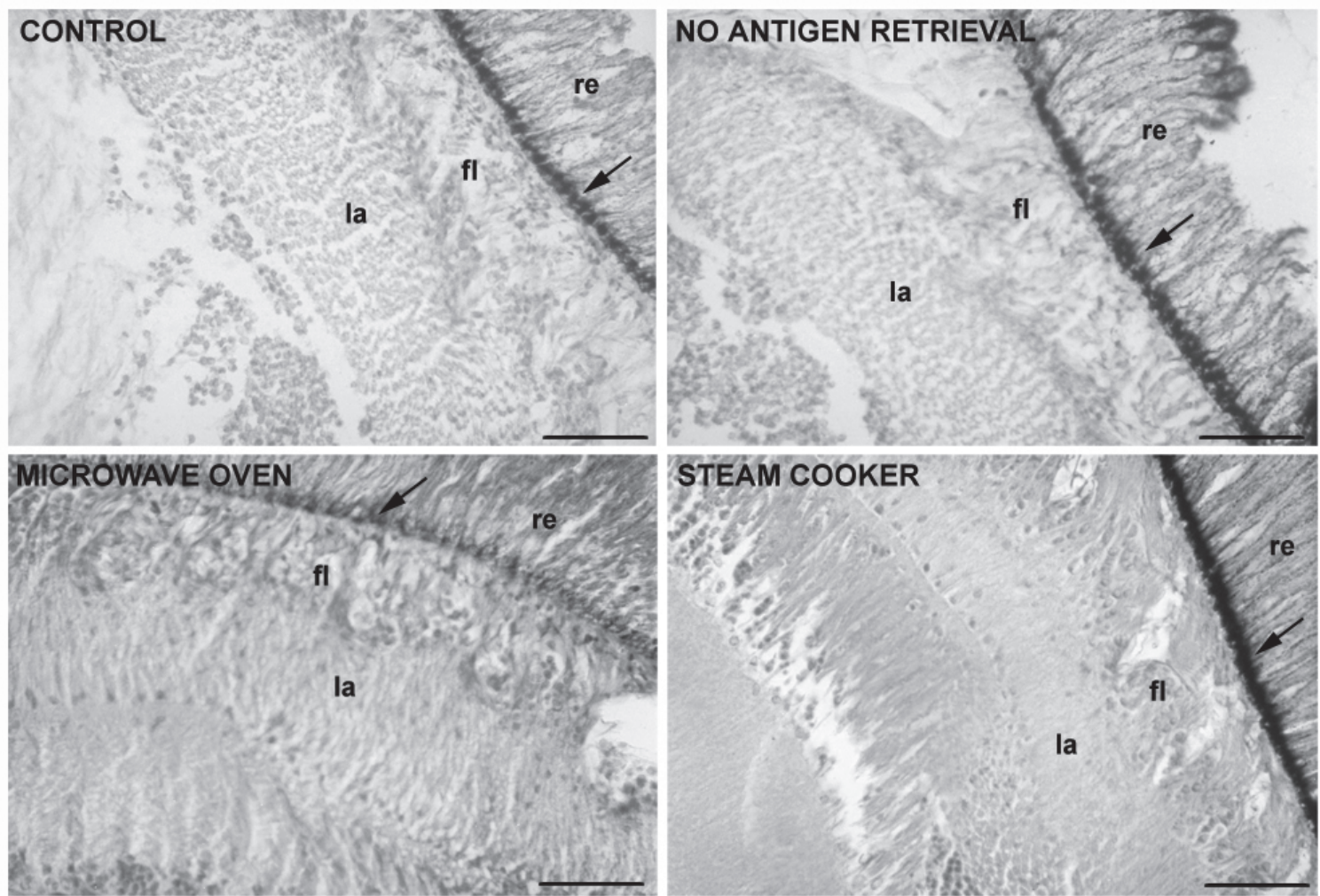

Figure 2: Detection of myosin- $\mathrm{V}$ in the optical lobe depends on antigen retrieval method.

Note that the section not treated with antigen retrieval unmasks an epitope (no antigen retrieval). Sections treated with antigen retrieval reveal moderate (microwave oven) and strong immunostaining (steam cooker). Control included the absence of primary antibody and antigen retrieval with steam cooker (control). Subregions: retina (re), fenestrated layer (fl), lamina (la) and retinal pigmentation (arrow); Scale bar $=50 \mathrm{~mm}$. 
immunostaining of myosin-V. At the same time, when the steam cooker was more efficient for AR-IHC, probably because the temperature can be controlled and does not exceed $90{ }^{\circ} \mathrm{C}$.

The heat produced by steam heats the AR solution, thus with the steam cooker the tissues are morphologically preserved and the epitopes exposed. On the other hand, it is not possible to control temperature in the microwave oven and the high heat can morphologically destroy the tissue and mask the interactions of antigen and antibody. Similarly, Hayat ${ }^{36}$ revealed satisfactory results using high temperatures $\left(100{ }^{\circ} \mathrm{C}\right)$ for 10 minutes. Additionally, more satisfactory results were obtained using the steam cooker at $90-95{ }^{\circ} \mathrm{C}$ for 20 minutes.

The secondary and tertiary structures of epitopes subjected to heating are probably reconstituted in solutions with appropriate $\mathrm{pH}$, buffer and salt concentrations. These factors and others, such as molarity and the chemical composition of the AR solution, can act to standardize this method, as was shown in other studies $13,35,37,38$.

The $\mathrm{pH}$ of the sodium citrate buffer is very important because hydrolysis and the protein structures involved are $\mathrm{pH}$ dependent ${ }^{6}$. Otherwise, the presence of sodium chloride in the AR solution can preserve the structure of the polypeptides ${ }^{35}$.

Evaporation of the AR solution was reduced when the steam cooker was used. Thus, the molarity of the sodium citrate buffer $^{39}$ was stable, reducing background effects. In other studies it was reported that an AR solution with $0.01 \mathrm{M}$ sodium citrate at $\mathrm{pH} 6.0$ showed satisfactory results, preserving cell morphology when compared to other buffers with high $\mathrm{pH}$, or containing EDTA $^{13,36,40,41}$.

In the literature, the majority of the immunohistochemical findings obtained from the honeybee brain do not describe the use of AR because these experiments were done with tissues obtained using a cryotome for the preservation of antigenic properties and expression. In vertebrates, Martins et al. ${ }^{21}$ found that the localization of myosin- $\mathrm{V}$ in the Purkinje cells of human cerebellum tissue embedded in paraffin and fixed in formalin was identical to that observed in rat cerebellum prepared with a cryotome by Espindola et al. ${ }^{42}$.

Fixation in formalin and embedding in paraffin are not the best procedures for insect nervous system immunohistochemistry, as they interfere with the antigenic properties and the preservation of the tissue. Although the heating procedures used in this work are generally employed in studies of the vertebrate nervous system and are costeffective, it is up to the researcher to justify the use of these methods in other studies of the invertebrate nervous system.

For the honeybee Apis mellifera brain, we conclude that the standardization of the AR procedure in the steam cooker revealed more specific immunostaining for myosin- $\mathrm{V}$ in the optical lobe, reducing conflicting results and extending the possibility of using this method in other studies of the invertebrate nervous system, as well as studies involving analysis of mouse or rat brains morphology and immunohistochemistry.

\section{ACKNOWLEDGMENT}

We thank Prof. Dr. Wilson Felipe Pereira, Ph.D. (UFU) for the suggestions, support and availability of his laboratory, and Pablo Marco Veras Peixoto (New York University) for critically reading the manuscript. This work was supported by fellowship from FAPEMIG to LKC and RRT, CNPq to SMCG, and CAPES to ABPL.

\section{REFERENCES}

1. MONTERO, C. J. Histochem. Cytochem. 2003, 51, 1

2. SHI, S-R.; MARC, E. K.; KRISHAN, L. K. J. Histochem. Cytochem. 1991, 39, 741.

3. TAYLOR, C. R.; COTE, R. J. Immunomicroscopy: a diagnostic tool for the surgical pathologist. 2ed., WB Saunders: Philadelphia, 1994.

4. TAYLOR, C. R. Human Pathology 1994, 25, 2.

5. TAYLOR, C. R.; SHI, S-R.; CHEN, C.; YOUNG, L.; YANG, C.; COTE, R.J. Biotech Histochem. 1996, 71, 263.

6. SHI, S-R.; COTE, E. J.; TAYLOR, C. R. J. Histochem. Cytochem. 2001, 49, 931.

7. SUURMEIJER, A. J. H.; BOON, M. E. Eur. J. Morphol. 1993, 31, 144.

8. GOWN, A. M. Am. J. Clin. Pathol. 2004, 121, 172

9. TAYLOR, C. R.; COTE, R. J. Immunomicroscopy. A diagnostic tool for the surgical pathologist. 3ed., Elsevier Saunders: Philadelphia, 2005. 
10. LEONG, A. S-Y.; MILIOS, J. Appl Immunohistochemistry 1993, 1, 267.

11. CATORETTI, G.; PILERI, S.; PARRAVICINI, C.; BECKER, M. H. G.; POGGI, S.; BIFULCO, C.; KEY, G.; D'AMATO, L.; SABATTINI, E.; FEUDALE, E.; REYNOLDS, F.; GERDES, J.; RILKE, F. J. Pathol. 1993, 171, 83 .

12. IGARASHI, H.; SUGIMURA, H.; MARUYAMA, K.; KITAYAMA, Y.; OHTA, I.; SUZUKI, M.; TANAKA, M.; DOBASHI, Y.; KINO, I. APMIS 1994, 102, 295.

13. SHI, S-R.; IMAM, A.; YOUNG, L.; COTE, R. J.; TAYLOR, C. R. J. Histochem. Cytochem. 1995, 43, 193.

14. UMEMURA, S.; KAWAI, K.; OSAMURA, R. Y.; TSUTSUMI, Y. Pathol. Int. 1994, 45, 103.

15. BANKFALVI, A.; NAVABI, H.; BIER, B.; BOCKER, W.; JASANI, B.; SCHMID, K. W. J. Pathol. 1994, 174,223

16. PONS, C.; COSTA, I.; VON SHILLING, B.; MATIASGUIU, X.; PRAT, J. Appl. Immunohistochemistry $1995,3,265$.

17. NORTON, A. J.; JORDAN, S.; YEOMANS, P. $J$ Pathol. 1994, 173, 371.

18. MILlER, R. T.; ESTRAN, C. Appl. Immunohistochemistry 1995, 3, 190.

19. KAWAI, K.; SERIZAWA, A.; HAMANA, T.; TSUTSUMI, Y. Pathol. Int. 1994, 44, 759

20. PASHA, T.; MONTONE, K. T.; TOMASZEWSKI, J. E. Lab. Invest. 1995, 72, 167.

21. MARTINS, A. R.; DIAS, M. M.; VASCONCELOS, T. M.; CALDO, H.; COSTA, M. C. R.; CHIMELLI, L.; LARSON, R. E. J. Neurosci. Methods 1999, 92, 25.

22. CHENEY, R. E.; O'SHEA, M. K.; HEUSER. J. E.; COELHO, M. V.; WOLENSKI, J. S. Cell 1993, 75, 13.

23. TITUS, M. A. Trends Curr. Biol. 1997, 7, 119.

24. MERCER, J. A.; SEPERACK, P. K.; STROBEL, M. C.; COPELAND, N. G.; JENKINS, N. A. Nature 1991, 349,709

25. ESPREAFICO, E. M.; CHENEY, R. E.; MATTEOLI, M.; NASCIMENTO, A. C.; DE CAMILLI, P. V.; LARSON, R. E.; MOOSEKER, M. S. J. Cell Biol. $1992,119,1541$.
26. TITELLI, C. Q.; MARTINS, A. R.; LARSON, R. E.; GARCIA-CAIRASCO, N. Neuroscience 2003, 121, 573

27. MOSSEKER, R. L.; CHENEY, R. E. Annu. Rev. Cell Dev. Biol. 1995, 11, 633 .

28. HASSON, T.; MOOSEKER, M. S. Curr. Opin. Cell Biol. 1995, 7, 587.

29. HIROKAWA, N. Science 1998, 279, 519.

30. ESPINDOLA, F. S.; SUTE, D. M.; PARTATA, L. B. E.; CAO, T.; WOLENSKI, J. S; CHENEY, R. E.; KING, S. M.; MOOSEKER, M. S. Cell Motil. Cytoskeleton 2000, 47, 269.

31. MCLEAN, I. W.; NAKANE, P. K. J. Histochem Cytochem. 1974, 22, 1077.

32. BOENISCH, T. J. Histochem. Cytochem. 2006, 54, 961.

33. RAIT, V. K.; XU, L.; O'LEARY, T. J.; MASON, J. T. Lab. Invest. 2004, 84, 300.

34. SOMPURAM, S. R.; VANI, K.; MESSANA, E.; BOGEN, A. S. Am. J. Clin. Pathol. 2004, 121, 190.

35. YAMASHITA, S.; OKADA, Y. J. Histochem. Cytochem. 2005, 53, 13 .

36. HAYAT, M. A. Factors affecting antigen retrieval. Microscopy, Immunohistochemistry, and Antigen Retrieval Methods for Light and Electron Microscopy. 1ed., Kluwer Academic: New York, 2002.

37. EVERS, P.; UYLINGS, H. B. M. J. Histochem Cytochem. 1994, 42, 1555

38. SHI, S-R.; COTE, E. J.; TAYLOR, C. R. J. Histochem Cytochem. 1997, 45, 327.

39. HOETELMANS, R. W. M.; VAN SLOOTEN, H-J.; KEIJZER, R.; VAN DE VELDER, C. J. H.; VAN DIERENDONCK, J. H. Biotechnic Histochem. 2002, $77,137$.

40. EHARA, H.; DEGUCHI, T.; KOJI, T.; YANG, M.; ITO, S.; KAWADA, Y.; NAKANE, P. K. Acta Histochem. Cytochem. 1996, 29, 311.

41. BATTIFORA, H. J. Histotechnol. 1999, 22, 169.

42. ESPINDOLA, F. S.; ESPREAFICO, E. M.; COELHO, M. V.; MARTINS, A. R.; COSTA, F. R.; MOOSEKER, M. S.; LARSON, R. E. J. Cell Biol. $1992,118,359$ 